\title{
Conclusions: Religious Literacy Promotes Absorptive Capacity, Inclusion and Reflexivity in Society
}

\author{
Timo Aarrevaara, Tuula Sakaranaho, and Johanna Konttori
}

\begin{abstract}
In this book we have sought new perspectives for religious literacy by defining it as a governance function in society. This concluding chapter examines the frameworks for creating new knowledge and skills for actors in the civil service, in other service sectors and industry by considering the expositions of chapter authors elsewhere in the book. As noted variously by the authors, there is no unified scholarly debate on religious literacy, but there is a debate that should be recognised in Finnish society with its expanding pluralism by understanding how secular laws and religious practices intersect will be greatly improved as increased religious literacy develops in Finland. Religious literacy should be seen broadly within civil administration as a key factor in its performance.
\end{abstract}

Keywords Religious literacy $\cdot$ Governance $\cdot$ Civil service $\cdot$ Absorptive capacity

In this volume, the focal point is religious literacy and illiteracy in secular society, and the chapters have presented discussion on the theme of religious literacy in different contexts of the religious landscape, where the aspect of utilisation of religious debate is a common feature. In the civil service, the theme can be viewed as a performance factor. Requirements imposed on authorities' capacity for religious literacy increased during the 2010s. Religious literacy can be necessary general knowledge for an authority but managing the theme can also have practical meaning. Accountability, transparency and dynamism are key elements of governance, and we examine this phenomenon with the concepts of absorption, inclusion and reflexivity. Religious debates culminate in these modern characteristics of governance. To make these principles a useful tool for a relationship between the operating environment and the organisation, we have interpreted religious literacy as a contingency. This

\author{
T. Aarrevaara $(\varangle)$ \\ University of Lapland, Rovaniemi, Finland \\ e-mail: timo.aarrevaara@ulapland.fi \\ T. Sakaranaho $\cdot$ J. Konttori \\ University of Helsinki, Helsinki, Finland
}

(C) The Author(s) 2020

T. Sakaranaho et al. (eds.), The Challenges of Religious Literacy,

SpringerBriefs in Religious Studies, https://doi.org/10.1007/978-3-030-47576-5_7 
contingency may be the effect of the operating environment on building an organisation or managing it, or finding ways to manage uncertainty (Aarrevaara et al. 2017).

\section{Religious Literacy and Administrative Practices}

Contingencies are effective and efficient features of organisations that support them to do the right things at the right time (Pfeffer and Salancik 2003). Contingencies can shape administrative practices in both loosely coupled religious communities and in tightly organised administrative organisations. Professionalism in administration is the ability to increase absorptive capacity, which refers to recognising and utilising external properties in the actions and work of the administration (Schmitt and Klaner 2015). This comes out well in Teemu Pauha's and Johanna Konttori's chapter on the mosque debate. According to them, it is not possible for an administration to pick one definition over others. They identified tensions between electoral candidates' commitment to religious freedom and their opposition to the proposed mosque. The authors also referred to the sociologist of religion Allievi's (2014) analysis on European debates about mosques. He has noted that the resistance to mosques can be roughly divided into two categories. On one hand, people are against mosque plans because of the tangible effects that mosques are supposed to have. These include the decline in property values, noise, increased traffic, and violent crime. On the other hand, some oppose mosques for cultural reasons, for example, because Islam is perceived as being incompatible with European values.

Religious literacy can contribute to the absorptive capacity of the administration to identify areas of activity in which the functions of civil administration are important. Absorptive capacity also means the ability to bring out essential religious themes, consistently deal with religious themes in stakeholder action, and the ability of authorities to bring religious issues into arguments in civil proceedings.

Another important feature of administration is inclusion as a characteristic of cognitive structures forming common perceptions. It can be seen as an ability to interpret and utilise the new knowledge and skills of administrators in understanding religious literacy. In this book, Marja Tiilikainen and Tarja Mankkinen present a relevant perspective on tackling strategic opportunities and actions to increase the capacity of governance. From this angle, reflexivity means capacity for strategic opportunities and increasing understanding of religious literacy in government. According to the authors, the typical feature of the administration is the tensions between existing administrative practices and religious needs, and they call this more precisely a migrant integration-security nexus. The result of this inclusion is an increase in capacity that can utilise religious literacy and increase the capacity of civil administration. By defining these contingencies, the administration can find solutions or operational practices for significant religious-based problems in administration (Hamann 2017). 
The chapters in this book illustrate frameworks and practices that create the absorptive capacity to recognise religious literacy and use it in evidence-based decision making. There is a need to develop common perceptions that underpin the concept of inclusion as a means of understanding and interpreting religious literacy in the public administration, the third sector and industry.

Nykänen and Linjakumpu point out that religious and religion-related networks are embedded in secular institutions. These political and economic mechanisms have not yet been sufficiently studied in the scholarly literature. Based on the chapters in this book, religious literacy provides tools for government to operate in the framework of multicultural and multilevel governance. However, different solutions are offered in the chapters, depending on whether the aim is to influence tangible decisions as in a chapter on the mosque debate by Pauha and Konttori. Another angle is to enhance cultural diversity, as described elsewhere in this book by Al-Sharmani and Mustasaari in a chapter on governing divorce. The task of scholars is to produce research-based evidence for decision-making taking into account multidimensional secular and religious law.

For governments it is a challenge to create capacity in public administration for intra-religious diversity in practices of governance (Sakaranaho 2018, 2019). Based on experience from schools, Rissanen, Ubani and Sakaranaho have noted that governance is effective if it is based on interdependence and negotiation. The tools needed for better governance include more evaluation and development if governance policies relating to religion. Tiilikainen and Mankkinen point out that governments have tangible needs to wind partnerships with faith communities into existing governance structures. These include supporting people's personal choices as well as preventing violent radicalisation.

The third factor is reflectivity as an ability to predict future actions of civil administration. In the past few years, there has been a strong trend in Europe to boost the administration's ability to engage in societal interaction on key issues, and to draw conclusions from the dialogue about the future (Rask et al. 2018). Aini Linjakumpu and Tapio Nykänen found religiously-motivated practices and social networking. For them, religious literacy is a key skill that the administration needs to have to hold a debate on entrepreneurship as one of the major drivers of society and the economy. A credible administrative review of these themes means a consistent dialogue with ethics and environment. It is a large challenge that this dialogue has a common framework and concepts that make it possible to set common goals and conclusions for different groups in this debate. Without this dialogue, significant resources related to the religion cannot be identified and recognized.

The above-mentioned three areas of religious literacy in civil service are combined with the drive for dynamic control, which refers to the ability of policy making to handle issues in a rapidly changing environment requiring a continuous dialogue about policies regarding religious themes in society. In this framework, dynamic governance refers to dynamic interactions between key actors as an exploratory, inductive approach in setting performance standards for good governance. 


\section{Towards Conceptual Frameworks of Religious Literacy}

Religious literacy is a unifying factor between the chapters of this book and serves as a conversation and framework for the meaning of religion in society. Thus, religious literacy does not constitute a unified scholarly debate, but rather a framework that can be interpreted by building capacity for governance, decision-making and social interaction. The aim of this summary is to bring out different contexts of religious literacy and find similarities and dissimilarities of understanding religious literacy. Here we also want to contribute to the debate concerning a useful conceptual framework of religious literacy in secular societies.

Our assumption in this book is that religious literacy is a pressing matter in all fields of a pluralistic society. The chapters confirm this view, but partly on different grounds. The chapter on Somali Finnish Divorce Practices by Mulki Al-Sharmani and Sanna Mustasaari, describes the approach of Islamic and Civic State Laws taking place in Finnish society governing religious pluralism. The chapter highlights the need to develop a religious literacy concept. Through this concept, actors in the divorce process can understand the factors that support the equal treatment of parties in administration and in the courts. Understanding the intersectionality of religious and secular laws can also provide enlightenment of the means by which it is possible for actors to be heard.

In this book, there is also criticism of the approach of interpreting religions as a special case. Religious identities, religious communities and individual believers choose some things from the religious basket and leave others behind. From a governance point of view, it is essential to identify the more important factors through religious literacy. The development of concepts and frameworks can enable authorities to identify essential problems and provide opportunities for discussion. From this perspective, religious literacy is social and civic competence in a pluralistic, welfare society.

The complexity of the religious questions in secular societies means that simply understanding the theme cannot provide guidance to the administration. Instead, the development of concepts and frameworks can enable authorities to identify the main problems and provide opportunities for discussion. From this perspective, religious literacy is needed in a social and welfare society. Multi-level governance means that religious communities can also become involved in individual solutions, social argumentation and decision-making.

The development of widely accepted concepts can be of decisive importance for trust-based and open-minded discussion between those involved in religion. It is largely about the themes that involve participation and discourse in decisionmaking and administration to promote the human capital of religious communities, and information and skilful actions in cooperation with the administration.

The chapters in the book deal with Finland, the civil administration of which has long been based on shared values. Finland makes an interesting reference country because multiculturalism has quickly become an important argument in society's decision-making and administration. In a chapter on religious literacy in education, 
Inkeri Rissanen, Martin Ubani and Tuula Sakaranaho define the role of multiculturalism and religion at school. For the older rather than the younger generations, religion seems to be a difficult matter to cope with. For the authorities such as principals and teachers, the relationship between religion and culture has become more complex in the 2010s.

The chapters in this book indicate that there are new data and frameworks that can be used to find interpretations and solutions to difficult problems concerning social, cultural and religious diversity. Although the themes and data in the chapters are different, common concepts can be found for them. Religious literacy in this context appears to be an argument for the decentralization of administration in a multi-level governance framework. Multilevel governance also implies a strong consideration of cultures and religions as a resource and a tool for shared practices between religious communities and the administration.

\section{References}

Aarrevaara, T., Wikström, J., \& Maassen, P. (2017). External stakeholders and internal practices in departments of teacher education at European Universities. Higher Education Quarterly, 71(3), 251-262.

Allievi, S. (2014). Mosques in Western Europe. Oxford Islamic Studies Online. Retrieved March 16, 2019, from http://www.stefanoallievi.it/2014/07/mosques-in-western-europe/.

Hamann, P. Maik. (2017). Towards a contingency theory of corporate planning-A systematic literature review. Management Review Quarterly, 67, 227-289.

Pfeffer, J., \& Salancik, G. R. (2003). The external control of organizations: A resource dependence perspective. Stanford, California: Stanford Business Books.

Rask, M., Mačiukaitė-Žvinienė, S., Taugiene, L., Dikcius, V., Matschoss, K., Aarrevaara, T., et al. (2018). Public participation, science and society-tools for dynamic and responsible governance of research and innovation. London and New York: Routledge.

Sakaranaho, T. (2018). Encountering religious diversity: Multilevel governance of Islamic education in Finland and Ireland. Journal of Religious Education, 66(2), 111-124.

Sakaranaho, T. (2019). The governance of religious education in Finland: A state-centric relational approach? In M. Ubani, I. Rissanen, \& S. Poulter (Eds.), Contextualising dialogue, secularisation and pluralism: Religion in Finnish public education (pp. 17-37). Münster: Waxmann.

Schmitt, A., \& Klaner, P. (2015). From snapshot to continuity-A dynamic model of organizational adaptation to environmental changes. Scandinavian Journal of Management, 31, 3-13. 
Open Access This chapter is licensed under the terms of the Creative Commons Attribution 4.0 International License (http://creativecommons.org/licenses/by/4.0/), which permits use, sharing, adaptation, distribution and reproduction in any medium or format, as long as you give appropriate credit to the original author(s) and the source, provide a link to the Creative Commons license and indicate if changes were made.

The images or other third party material in this chapter are included in the chapter's Creative Commons license, unless indicated otherwise in a credit line to the material. If material is not included in the chapter's Creative Commons license and your intended use is not permitted by statutory regulation or exceeds the permitted use, you will need to obtain permission directly from the copyright holder.

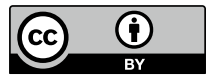

